\title{
René Girard a jeho mimetická teorie společnosti jako možné východisko k nové sociologické teorii
}

\author{
MARIÁN KIŠš $*$
}

\author{
René Girard and his Mimetic Theory of Society as a Potential Inspiration \\ to New Sociological Theory
}

\begin{abstract}
The presented article introduces René Girard's thought, especially the main components of his mimetic theory of culture. The author identifies in Girard's work two main lines of thought: firstly, the part which covers the psychosocial effects of mimetism on the micro-social level; secondly, the part which deals with the effects of mimetism on the macro-social level and with the impact it has on the genesis and preservation of social structure. The author further explicates Girard's understanding of ritual, myth, the sacred victim, the sacred monarchy and the relation between religion and society in general. The final part of the article considers the potential inspiration and relevance of Girard's work for sociological theory. The author argues that the primary task is now to examine the relation of Girard's thought to Durkheim's theory of society. He further suggests to take a new look (with the help of Girard's work) at the old theoretical dispute between Émile Durkheim and Gabriel Tarde, and examine, to bridge the differences between Durkheim and Tarde. The author considers such step especially relevant since Girard's thought is grounded in the Durkheimian tradition and - at the same time - Girard's key concept of mimesis plays central role in Tarde's sociology. This is the direction towards which the author intends to work further in his own research.
\end{abstract}

Keywords: René Girard, mimetic theory, mimesis, mimetic desire, violence, sacred, power, sociological theory, imitation, Émile Durkheim, Gabriel Tarde

René Girard patří k sociálním a kulturním teoretikům, jehož myšlenky nejsou v českém sociologickém prostředí prŕliš známé. ${ }^{1}$ Je to ale škoda, protože jeho dílo je myšlenkově i metodologicky velmi originální a inspirativní a jako takové může být podnětem k novému promýšlení řady důležitých teoretických problémů sociologie nebo může být také využito pro nový náhled na myšlenky sociologických klasiků. Tato studie si proto především klade za cíl představit Girardovy myšlenky, zejména pak hlavní prvky jeho mimetické teorie. ${ }^{2} V$ závěru textu naznačíme možné směry dalšího využití a rozvinutí Girardových myšlenek a girardovského hlediska v rámci sociologického myšlení.

* $\quad$ Mgr. Marián Kišš, Katedra sociologie, Filozofická fakulta Univerzity Karlovy, Celetná 20, 11642 Praha 1. E-mail: mariankiss@hotmail.com

1 René Girard se narodil 25. prosince 1923 ve francouzském Avignonu. V Paříži vystudoval historii a roku 1947 odjel do Spojených států na studijní pobyt, kde následně v roce 1950 získal doktorát na Indiana University v Bloomingtonu. V USA působil na několika univerzitách a roku 1961 se stal řádným profesorem na Johns Hopkins University v Baltimore. V roce 1981 se stal profesorem francouzské literatury, dějin a kultury na kalifornské Stanford University v Palo Alto, kde působil až do svého penzionování v roce 1995. V roce 2005 byl zvolen členem Francouzské akademie.

2 Termín „mimetický“ je zde odvozen od pojmu mimesis (latinsky imitatio), což je řecký termín pro imitaci, nápodobu či kopírování. V tomto textu budeme v duchu girardovské terminologie držet mimesis jakožto obecnějšího termínu. 


\section{Problém přístupu $\mathrm{k}$ interdisciplinárnímu a mnohovrstevnému Girardovu dílu}

Jedním z důvodů, proč Girardovo dílo není v českém sociologickém prostředí dostatečně známé, může být i skutečnost, že jeho myšlení není snadno zařaditelné a uchopitelné. Dílo tohoto myslitele je svým záběrem i východisky dílem interdisciplinárním a vskutku mnohovrstevným. Překračování hranic různých oborů vědění totiž představuje Girardovu oblíbenou pracovní metodou, což poněkud znesnadňuje jakýkoliv pokus o tradiční formu výkladu. Každá snaha o prezentaci Girardova díla a jeho myšlenkového systému tak nutně naráží na problém tématického a metodologického východiska.

Čelíme nutně problému, odkud vyjít a jakým způsobem onu mnohovrstevnost vtělit do přehledného tvaru. Protože není v možnostech tohoto článku postihnout všechny stránky Girardova myšlení, jako nejlepší řešení se nabízí představit jeho dílo s určitým tematickým akcentem, s ohledem na konkrétní publikum. ${ }^{3} \mathrm{~V}$ tomto textu se pokusíme k výkladu Girardova myšlenkového systému přistoupit z pozice, která by byla zajímavá pro sociology, sociální či kulturní antropology nebo jiné odborníky zabývající se sociální teorií. Zároveň s tím je třeba rozhodnout, zda Girardovo myšlení představit obvyklejším „encyklopedickým“ způsobem, kdy bychom prezentovali biografické údaje, myšlenkové vlivy, přehled základních prací atd., nebo naopak zvolit výklad „tematický“, který se zaměří na autorův myšlenkový systém a jeho klíčové motivy. V tomto textu zvolíme druhou variantu, kterou lze považovat užitečnější, pokud jde o faktografii; v nezbytném minimu ji připojíme v poznámkách.

Cílem předkládaného textu není kritická analýza Girardova díla a jeho myšlenkového systému. Ačkoliv je takový krok jistě velmi důležitý a potřebný (a někteří čtenáři jej zde mohou postrádat), nezbývá než v tomto odkázat na některou naši prřšsí studii. Prostor vymezený tomuto článku a poměrně komplexní tematika, o které pojednáváme, nám zde bohužel nedovolují více než nabídnout pouze stručný úvod do Girardova myšlení, spolu s načrtnutím výhledu směrem k sociologické teorii.

\section{Mimetická teorie a její první pilír}

Mimetická teorie ${ }^{4}$ představuje komplexní interdisciplinární teorii lidské kultury, která je založena na předpokladu psychologické mimesis. ${ }^{5}$ Girard tuto svou teorii rozvíjí v průbě-

3 Jedním z prrípadů, kdy autor takto postupuje, je monografie Michaela Kirwana René Girard: Uvedení do díla, která vyšla v českém překladu v roce 2008 v brněnském nakladatelství CDK. Kirwan, který je teolog, ve své práci akcentuje především náboženské souvislosti Girardova díla. Kirwanova práce je zřejmě jedinou monografií dostupnou v češtině, jež se systematicky zabývá Girardovým dílem.

4 Mimetická teorie bývá také označována za „mimetickou teorii společnosti“ nebo „mimetickou teorii lidské kultury“. Podrobné seznámení s Girardovým myšlením nabízejí především tyto autorovy práce: Mensonge romantique et vérité romanesque. Paris: Grasset, 1961, v českém překladu Lež romantismu a pravda románu [Girard 1998a]. La Violence et le sacré. Paris: Grasset, 1972, v anglickém překladu Violence and the Sacred [Girard 1977]. Des Choses cachées depuis la fondation du monde. Paris: Grasset, 1978, v anglickém překladu Things Hidden Since the Foundation of the World [Girard 1987]. Le Bouc émissaire. Paris: Grasset, 1982, v českém překladu Obětní beránek [Girard 1997]. Rovněž lze doporučit knihu Johna Williamse (ed.) The Girard Reader. New York: The Crossroad Publishing Company, 1996. Je možné využít i již zmíněnou Kirwinovu monografii René Girard: Uvedeni do díla. Dále CDK vydalo v roce 2008 knihu rozhovorů s René Girardem pod názvem O původu kultury. Zde autor osvětluje mimetickou teorii v širších souvislostech a komentuje svůj myšlenkový vývoj.

5 Psychologická mimesis je pojem popisující mechanismus, který je zodpovědný za přirozený sklon „lidských bytostí napodobovat gesta, jednání a záměry druhých lidí [srv. Garrels 2006: 48]“. Girard jako první myslitel přichází s uceleným teoretickým schématech, který pracuje se zákonitostmi psychologické mimesis. 
hu více než čtyřiceti let a kombinuje při tom poznatky z různých oborů včetně literární teorie, antropologie, sociální teorie, religionistiky či filozofie. ${ }^{6}$ Jeho teorii lze vymezit dvěma myšlenkovými pilî́ri. První piliŕr operuje s konceptem mimetické touhy a jejími širšími souvislosti a zabývá se psychosociálními účinky rozvinutých forem mimetismu na „mikrosociální“ úrovni, tj. se týká dvou, tř́i či několika jedinců. Druhý pilíř se zabývá působením mimetismu na „makrosociální“ úrovni a všímá si také role tohoto fenoménu při vzniku a udržení sociálního řádu. Girard se zde rovněž zabývá mechanismem obětního beránka, institucí posvátné oběti, rolí, jakou tato obět sehrává v archaickém náboženství a obecněji se věnuje vztahu mezi náboženstvím a společností.

Výchozím bodem celého Girardova teoretického systému a základním stavebním kamenem jeho antropologie je koncept mimetické touhy. K tomu se Girard dopracovává zajímavým zpo̊sobem, na základě „antropologického“ zkoumání literárních děl velkých romanopisců, mj. Cervantese, Stendhala, Flauberta, Prousta či Dostojevského se zaměřuje na literární zobrazování psychosociálních souvislostí lidských vztahů. Přitom zjištuje, že je to právě fenomén touhy, jež tvoří základní konstantu jak vnitřního života jedince, tak i všech jeho sociálních vztahů. Girard také dospívá k závěru, že velcí romanopisci nám s hlubokým porozuměním pro individuální i sociální psychologii umožňují pochopit, že tato touha nikdy nevychází z nitra konkrétní postavy (tedy že ve skutečnosti není „autonomní“ touhou), ale že se vždy jedná o touhu zrozenou z nápodoby, o touhu získanou prostřednictvím jiné osoby, touhu mimetickou.

Platí-li, jak Girard říká, že „každá touha vede skrze druhé [Girard 2008: 45]“, je touha vždy vymezená základním trojúhelníkovým schématem, jehož tři body tvoří „subjekt touhy“, „prostředník touhy“ a „objekt touhy“. Právě takovýto trojúhelník touhy představuje podle Girarda základní psychosociální vzorec lidských vztahů. Každá touha zde předpokládá svého prostředníka jako osobu, která u jiného člověka určitou touhu probudí a nasměruje ji ke konkrétnímu objektu či cíli (který může být i zcela abstraktní). To ovšem znamená, že každá touha subjektu je na daný objekt zaměřena vždy až sekundárně; primárně je soustředěna na Druhého, na svého mimetického prostředníka. V základním trojúhelníku touhy se tak vytváří zvláštní vztah existenciální závislosti mezi Já a Druhým: Girard si u zkoumaných spisovatelů všímá, že „všichni románoví hrdinové očekávají od skutečnosti, že se zmocnili objektu, radikální proměnu svého bytí [Girard 1998a: 65]“. „Touha podle Druhého“ je totiž podle Girarda „vždycky touhou být Druhým [tamtéž: 97]“. Když subjekt imituje prostředníka, nejen že chce mít to, co má on, ale v podstatě chce zaujmout jeho místo, být jako on.

Ukazuje se až jakýsi kvazi-náboženský rozměr onoho základního vzorce lidských vztahů. Pozorujeme určité zbožštění prostředníka, existenciální závislost subjektu na něm a od ní se odvíjející moc, kterou prostředník vůči subjektu disponuje. Girard v souvislosti s mimetickou touhou někdy také mluví o touze „bez-objektové“ (případně „,metafyzické“) a konstatuje, že nic nemůže být méně materialisticky orientovaného než mimetická touha: „Vášeň, ženoucí lidi, aby se rvali o objekty nebo aby je rozmnožovali, není

6 Zde stojí za zmínku, že Girard byl v minulosti kritizován za to, že mimetická teorie - a zvláště pak jeho předpoklad psychologické mimesis - jsou př́liš spekulativní a nevědecké, protože nejsou dostatečně empiricky podložené. V posledních letech se ovšem klíčové teze Girardova myšlení dočkaly široké podpory právě ze strany empirického výzkumu, zvláště v oblasti vývojové psychologie a kognitivní neurovědy [více viz Garrels 2006]. 
vítězstvím hmoty, ale vítězstvím prostředníka - boha s tváří člověka. (...). Úměrně tomu, jak se vylidňuje nebe, proudí posvátnost zpět na zem (...) [tamtéž: 74].“

Právě s tímto mechanismem Girard také ztotožňuje hlubokou moderní závislost na Druhém, onu neustálou potřebu srovnávání a připodobňování se Druhému. Tato posedlost Druhým má za následek nejen neustálé bloudění z objektu na objekt a honbu za objekty stále novými, ale také ustavičné těkání mezi prostředníky. Tento stav, směřující až k rozkladu individuální osobnosti v důsledku zmnožování prostředníků, ve svém díle podle Girarda nejlépe zachycuje Dostojevskij:

„Oč je vláda prostředníka kratší, o to je i despotičtější. Největší utrpení je tedy vyhrazeno hrdinům Dostojevského. U člověka z podzemí je sled prostředníků tak rychlý, že už nelze hovořit o různých Já. (...) Prvky, které jsou u ostatních romanopisců hierarchizovány (...) jsou zde ponechány ve stavu chaosu. Člověk z podzemí je i často rozčtvrcen mezi několik prostřednictví. (...). Tou měrou, jak se prostř̌edník přibližuje, jednota se rozpadá na mnohost. Sestupuje se zde stupňovitě od jedinečného, nadčasového a smyšleného prostředníka Dona Quijota k vřavě Dostojevského. Těch 'pět nebo šest modelů', na které se podle Stendhalových slov rozděluje 'dobrá společnost' jeho doby, a násobky proustovského Já jsou etapami tohoto sestupného pochodu. Démon Běsů se jmenuje zástup a vejde do stáda vepřủ. Je současně jeden i mnohonásobný. Tato atomizace osobnosti je koncem vnitřního prostřednictví [tamtéž 106].“

Podle Girarda je to právě Dostojevskij, kdo nejhlouběji analyzuje rozkladný účinek touhy a v moderním narcismu odhaluje chorobnou závislost na Druhém jakožto formu moderního sebe-zotročení člověka [Girard 2002: 33], čímž s definitivní platností rozbíjí romantickou oslavnou představu autonomního jedince [Boorstin 1996: 797-798]. Rozklad moderního subjektu v důsledku mimetické touhy ovšem nemá destruktivní vliv jen na individuální existenci, ale také na existenci kolektivní: „Prázdný eklekticismus, přechodná zaujatost, stále prchavější metody, stále rychlejší výměna teorií, systémů a škol, a ono ‘zrychlování dějin’ [Girard 1998a: 108]“, všechny tyto průvodní jevy modernity jsou podle Girarda důsledkem vystupňovaných účinků mimetické touhy a výrazem zmnoženého prostřednictví.

Navenek se zmnožené mimetické prostřednictví a z něj plynoucí mimetické soupeření může projevovat $\mathrm{v}$ materialistickém konzumismu - byt', jak jsme již viděli, je touha svou podstatou „bez-objektová“. Jak si například všímá jeden ze sociologických klasiků Thorstein Veblen (jehož uvažování v problematice touhy a rivality je velmi girardovské), dokonce i samou instituci vlastnictví můžeme považovat za prrímý důsledek soupeření [Veblen 1999: 26]. Podobně i lidský sklon ke shromaždování hmotných statků není motivován nějakou objektivní potřebou, ale soupeřením: „Žádné všeobecné zvýšení blahobytu, “ píše Veblen, „nemůže přiblížit uspokojení potřeby, jejíž základ spočívá $v$ touze každého předčit všechny ostatní v hromadění statků [tamtéž: 31, kurzíva $M$. K.].“ A právě sklon k (mimetickému) soupeření je podle Veblena také hlavním hybatelem celého kapitalistického systému a vede k neomezenému nárůstu touhy, která toto soupeření zpětně dál posiluje:

„Nepočítáme-li pud sebezáchovy, představuje sklon $k$ soupeření podle všeho nejsilnější, nejčilejší a nejstálejší z ekonomických motivů. V průmyslových společnostech se tento sklon projevuje v peněžní a majetkové rivalitě, tj. (...) v nějaké formě okázalého plýtvání. Potřeba okázalého plýtvání je tedy s to pohltit jakékoli zvýšení 
výrobní kapacity a jakýkoli nárůst produkce statků nad rámec toho, co je zapotřebí k uspokojení nejzákladnějších fyzických potřeb. (...) I když větší výkonnost výroby umožňuje pořizovat prostředky k živobytí s menším vynaložením sil, přičinliví členové společnosti nijak nezvolňují tempo a svou energii zaměřují na dosahování lepších výsledků v okázalých výdajích. Úsilí neochabuje a nadprodukce je použita k uspokojování této potřeby, která může neomezeně narůstat (...) [tamtéž: 89, kurzíva M. K.].“

Všimněme si, že veblenovská touha, a z ní plynoucí sklon k soupeření, je přesně v Girardově duchu „bez-objektová“. Ačkoliv se vnějškově může jevit jako „objektová“, nejlepším dokladem její pravé povahy je, že ji nelze uspokojit a neustále roste [tamtéž: 31]. Veblenovy závěry tak zde přesně odpovídají Girardovu schématu touhy a představují vlastně aplikaci tohoto schématu na fungování socio-ekonomického systému.

Trojúhelníkové schéma mimetické touhy ovšem nesměřuje jen ke zvláštní existenciální závislosti mezi Já a Druhým, nebo k majetkovému soupeření, ale rovněž zásadním způsobem problematizuje lidské vztahy. Platíli totiž, že nadšení subjektu pro objekt je především nadšením pro mimetického prostředníka a „subjekt touží po objektu, který vlastní nebo si přeje jeho vzor [Girard 2008: 47, kurzíva M. K.] “, pak se tento prostředník na cestě subjektu k vytouženému objektu zároveň stává mimetickou překážkou. Girardovo schéma tak dobře osvětluje paradox, že tatáž síla (tedy mimetická touha) lidi sbližuje a poutá do vzájemných závislostí, ale je zároveň i zdrojem všech rozepří a konfliktů v lidských vztazích. Girardovo schéma touhy tak odhaluje mechanismus, skrze který se (obdivovaný) mimetický vzor či prostředník proměňuje v (nenáviděného) mimetického

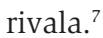

Právě mimetická rivalita tak podle Girarda představuje další stádium mimetické touhy, které může vyústit až v násilný mimetický konflikt. Ten lze považovat za poslední stádium mimetické touhy, kdy se vztah mimetické závislosti, ve kterém původně vládla reciprocita touhy, promění v reciprocitu násilí. Jak konstatuje Girard, subjekt se nakonec „stává vzorem svého vzoru a napodobující napodobuje toho, kdo jej napodoboval. Vývoj směřuje ke stále větší mimetické reciprocitě, a tedy k většímu konfliktu. Mezi soupeři objekt mizí ze zřetele a jejich jediným a nutkavým přáním už není jej získat, ale porazit protivníka [Girard 2008: 48].“

\section{Mimetická teorie a její druhý pilíř}

Účinky mimetické touhy ovšem Girarda nezajímají pouze na „mikroúrovni“ individuálních vztahů, ale zkoumá je také ve vztahu k otázce vzniku a udržení sociálního a kulturního řádu. Girard si všímá, že na sociální „makroúrovni“ může v důsledku nekontrolovaného mimetismu dojít k situaci, kterou nazývá mimetickou krizí. Jedná se o stav, kdy ve společenství dochází ke zmnožení mimetických prostředníků, což může podnítit vznik řady nekontrolovaných mimetických rivalit, které zapř́íčiní, že se společenství začne pod tlakem vnitřního násilí rozkládat. ${ }^{8}$ „Nápodoba je vždy impulsem pro rivalitu

7 Girard popsané zákonitosti zkoumá v knize Lež romantismu a pravda románu na př́kladech různých literárních postav již zmiňovaných romanopisců a ukazuje, že nejrůznější psychosociální obrazce jako závist, nenávist, nepřátelství, či dokonce sadismus nebo masochismus jsou jen funkčními variacemi na ono základní trojúhelníkové schéma touhy.

8 Otázka role rivality a násilí při vzniku a udržení sociálního řádu, jak o ní Girard pojednává, v mno- 
[tamtéž: 55]“, říká Girard, takže když „mimetická mašinérie funguje v kruhu násilí, v obousměrném napodobování, nastřádá se v ní konfliktní energie, která pochopitelně slouží k jejímu rozpínání všemi směry. Mechanismus postupně nabývá na přitažlivosti, mimeticky řečeno, pro všechny v okolí; když se dva perou o jednu věc, pro třetího, který to soupeření sleduje, její hodnota narůstá, takže láká stále více osob v dosahu [tamtéž: 58]“. V takové situaci má společenství postižené podobnou krizí podle Girarda jedinou možnost, jak se vymanit $\mathrm{z}$ kruhu násilí a zachránit se před sebezničením, totiž soustředit „veškerý hněv společenství na jednu obět', která vyplyne z miméze samé a na níž se všichni jednomyslně shodnou. S rozumem zakaleným mimetickým násilím se snadno najde společný jmenovatel, jeden člen společenství, kterého označí za jedinou příčinu krize. (...) Mechanismus obětního beránka kolektivní násilí celého společenství nasměruje proti jednomu jeho členovi, náhodně vybranému, a tato obět se stává nepř́telem celé komunity, která je in fine usmírena. Mimetická povaha tohoto procesu je nejnázorněji patrna z rituálů, v nichž se jednotlivé úseky popsaného scénáře opakují. Zajímavé je, proč rituál často začíná úmyslným porušením řádu, umělou, inscenovanou krizí, jak konstatují etnologové, a vrcholí rituálním obětováním. Odpověd’ zní - protože jde o to zopakovat mimetickou krizi, která spontánně vede k mechanismu jediné oběti [tamtéž: 58-59].“

To, co zde máme ve zkratce popsáno v obecném schématu, tvoří součást obětního mechanismu, který představuje druhý piliř Girardovy mimetické teorie. Zatímco první pilîr vychází z konceptu mimetické touhy a jejích souvislostí, druhý pilî́r řeší otázku mimetické krize, problematiku sociálního řádu a mechanismus obětního beránka, což je nevědomě působící psychosociální vzorec, který pomáhá překonat sociální krizi a př̀směrováním mimetického násilí (znovu)nastolit řád. V Girardově pojetí se vlastně jedná o novou teorii vzniku a udržení sociálního řádu, která pracuje s účinky psychologické mimesis. Podívejme se ted’ podrobněji na Girardovy myšlenky týkající se právě druhého pilíře mimetické teorie a zaměřme se na jeho výklad obětního rituálu, mytologie a sociální funkce posvátné oběti.

\section{Druhý pilír mimetické teorie a problematika rituálu}

Girard vychází z předpokladu mimetické povahy lidských vztahů a své úvahy začíná u archaických a primitivních ${ }^{9}$ společností, kdy se soustředí na základní stavební kameny jejich náboženských a sociálních systémů, tedy na rituály a mýty. (Girardovo zkoumání je usnadněno předpokladem, že v těchto společnostech je vazba mezi náboženskou a sociální strukturou natolik silná, že mezi nimi lze jen těžko rozlišovat. ${ }^{10}$ ) Rozborem starých mýtů a rituálů dospívá Girard k závěru, že obě tyto kulturní formy jsou výtvorem jednoho mechanismu, který umožňuje vznik a udržení sociální struktury. Všímá si také, že právě udržení sociální struktury představuje pro malé společnosti s jednoduchým uspořádáním ${ }^{11}$ zvlášt naléhavý problém, protože jakýkoliv silnější násilný impuls či vnitřní krize

hém evokuje motivy, které nacházíme např́klad v sociální a politické filozofii Thomase Hobbese (v Leviathanovi). Bylo by zajímavé podrobněji srovnat Girardovy úvahy s Hobbesovými myšlenkami. Girard sám na Hobbese ve svém díle několikrát odkazuje [srv. Girard 2008: 58].

9 Termín „primitivni““ zde, stejně jako Girard, používáme v nehodnotícím smyslu.

10 V tomto je Girardovo stanovisko a metoda velmi podobná stanovisku Durkheimovu [srv. Keller 2007: 220-227].

11 V durkheimovské terminologii by šlo o společnosti segmentární, kde převládá mechanická solidarita [srv. Keller 2007: 208-210]. 
pro ně může mít fatální následky. Již jsme viděli, že mimetismus - který představuje základní princip mezilidských vztahů, základní antropologickou konstantu [Girard 1998b: 130] - je potenciálním zdrojem sociálně rozkladných impulsů, takže archaické společnosti podle Girarda žijí pod neustálou hrozbou mimetické krize a mimetického násilí. ${ }^{12}$ A protože hrozba takové krize $\mathrm{v}$ důsledku vnitřních konfliktů není u těchto společností nikdy definitivně zažehnána, časem se v nich podle Girarda vyvinuly preventivní mechanismy, jež působí proti nebezpečí násilné reciprocity a vnitřní (mimetické) krize.

Prvním takovým mechanismem je náboženské tabu, což je přísný kulturní zákaz, který nežádoucí sociální situaci zabraňuje tím, že ji preventivně vylučuje. Druhým mechanismem pak je náboženský rituál, přičemž Girardovu pozornost zde poutá především rituál obětní, který se s pozoruhodnou pravidelností objevuje v primitivních společnostech a náboženstvích celého světa. Girard z toho vyvozuje, že právě obětní rituál - jehož hlavní sociální funkcí je podle něj chránit společenství před vnitřním násilím a sociálním rozkladem - představuje základní a vývojově nejstarší rituální mechanismus, a jako takový je klíčem k porozumění prazákladům lidské kultury i náboženství. ${ }^{13}$

Girardovy úvahy o rituálu vycházejí ze závěrů Godfrey Lienhardta a Victora Turnera, kteří na základě zkoumání afrických kmenů ukazují, že u některých z nich obětní mechanismus představuje záměrné jednání využívající principu kolektivního nahrazení, které probíhá „na úkor oběti a jehož cílem je zmírnit všechna vnitřní napětí, spory a soupeření nashromážděné v rámci daného společenství [Girard 1977: 7]“. Kolektivní obět zde plní konkrétní funkci, totiž

„(...) představuje náhradu za všechny členy společenství, kterou oni sami obětují. Instituce oběti slouží $\mathrm{k}$ tomu, aby ochránila celé společenství před jeho vlastním násilím; vede dané společenství k tomu, aby obět vybíralo mimo okruh svých vlastních členů. Různé nesváry existující uvnitř komunity se soustředí na osobu oběti a prostřednictvím obětního mechanismu jsou - alespoň dočasně - odstraněny. (...)

Je jednoduché vysmívat se náboženství, pokud se soustředíme na jeho okrajovější rituály, jako jsou třeba ty, které mají přivolat déšt nebo přinést dobré počasí. Ve skutečnosti neexistuje žádný cíl nebo aktivita, v jejichž jménu by nebylo možné praktikovat obětní rituál, zvláště pokud se začíná vytrácet vědomí společenských souvislostí tohoto aktu. Existuje nicméně společný jmenovatel, na němž účinnost

12 To mívá za následek až panickou hrůzu těchto společností z násilné reciprocity a jejich obavy mohou v této souvislosti vyvolávat i jevy nebo objekty, které tuto reciprocitu třeba jen vzdáleně připomínají (např. obava z dvojčat, které někdy bývají i zabíjeny, strach z pouhé fyzické podobnosti dvou lidí, ze zrcadel atd.), takže pro vnějšího pozorovatele může být velmi těžké porozumět pravým příčinám podobných obav. Jak ale Girard dokládá, vždy se jedná o jevy, které v mysli archaického člověka evokují násilnou reciprocitu a krizi sociálního řádu, protože symbolizují ztrátu rozdílů a krizi rozlišování, které s sebou mimetická krize vždy nese.

13 Girard v této souvislosti vymezuje tř̌i rituální vývojová stádia ochrany proti vnitřnímu násilí. Za prvé preventivní forma obětního rituálu, kdy jsou násilné impulsy usměrněny v rámci pevně stanoveného rituálního rámce. Za druhé usměrňování aktů odplaty prostřednictvím náhradních mechanismů, jako je tomu například v rámci ritualizovaných soubojů („boží soud“). Za třetí ustanovení soudního systému. Funkce všech tří mechanismů je přitom totožná, tj. chránit společenství před vlastním násilím. Podle Girarda je nám třetí forma myšlenkově nejbližší, a proto propadáme často mylnému dojmu, že zbylé systémy jsou v nějakém ohledu nesmyslné nebo iracionální. Tak tomu ale není, jeví-li „se nám náš systém jako racionálnější, je to proto, že se důsledněji řídí principem msty. Dưraz našeho systému na potrestání viníka tuto skutečnost podtrhuje. „Namísto toho, aby (...) se snažil předejít aktům odplaty a zklidňoval nebo narušoval jejich účinky nebo je přesměrovával k zástupným objektům, náš soudní systém odplatu racionalizuje a daří se mu tak omezit její projevy v souladu s požadavky společnosti [Girard 1977: 21-22].“ 
všech obětních praktik záleží a který se stává tím zřetelnější, čím více sílí instituce oběti. Tímto společným jmenovatelem je vnitřní násilí - tedy všechny neshody, rivality, nevraživosti a spory uvnitř společenství-, k jejichž potlačení mají obětní rituály sloužit. Cílem instituce oběti je obnovení řádu uvnitř společenství, upevnění sociální struktury [tamtéž: 8].“

Girard je přesvědčen, že prehistorie lidských společenství byla v důsledku nekontrolovaného mimetismu plná střetů a spontánních výbuchů násilí. A s tím, jak u vývojových předchůdců člověka (zřejmě v důsledku zvětšujícího se mozku) sílila mimetická složka jejich přirozenosti, přestávaly zároveň působit ustálené vzorce dominance, které zajištují stabilitu společenské struktury ve zviŕecí říši. Proto podle Girarda došlo k situaci, že lidská společenství v určité fázi vývoje nedisponovala žádným mechanismem, který by byl schopen sílící konfliktní stavy transformovat ve stabilní sociální strukturu. Právě někde tady dochází k pozoruhodnému vývojovému skoku, kdy se mimetická rivalita a násilná reciprocita prostřednictvím nového - obětního - mechanismu proměňuje v sociálně integrující sílu.

Girard tuto podivuhodnou proměnu vysvětluje zvláštní vlastností násilí, které „umí“ zaměnit jeden cíl za jiný a vybít se na zástupných objektech, které nemusejí mít nic společného s podnětem, který násilí původně vyvolal. Další důležitou vlastností násilí je jeho schopnost mimetického „nabalování“. Tyto dva mechanismy v součinnosti pak podle Girarda vedou k tomu, že v situaci, kdy existuje nepřehledná změt vztahů mimetické rivality a násilí, se násilné impulsy začnou spontánně slévat, až v rámci společenství vznikne jediný proud násilí. Původní nepřehledná násilná reciprocita se tak proměňuje v obrazec, kdy násilí začíná směřovat do jednoho bodu, na jedinou obět [Girard 1998b: 133], kterou zaměřilo zpravidla na základě nějakého náhodného podnětu. To ale stačí, aby se tato obět stala terčem veškeré negativní energie původně rozptýlené mezi mnoha jedinci. Situace všeobecné mimetické krize, kdy kolektivní mimetismus vede k tomu, že „imitace napodobuje imitaci a kdy násilí napájí samo sebe [Bottum 1996:]“, tedy vrcholí tím, že mechanismus zástupné oběti (v důsledku přirozené dynamiky násilí) proměňuje původní schéma všech proti všem na schéma všech proti jednomu. ${ }^{14}$ Násilí si tak vlastně samo „Zvolí“ svou obět a společenství (aniž by si to uvědomovalo) se očištuje od svého vlastního násilí, čímž dochází k jeho uklidnění a (re)integraci [srv. Taylor 1998: 137]. Konfliktní a násilná mimesis se tak spontánně proměňuje v mimesis smírnou a jednotící [Girard 2008: 59].

Girard je přesvědčen, že popsaný mechanismus se ve společenstvích pre-hominidů spontánně opakoval po stovky tisíc let a měl tak silný formativní vliv nejen na sociální strukturu, ale také na vývoj psychické struktury zúčastněných [srv. Lefebure 1996: 1226-1227]. Účinek tohoto stále se opakujícího mechanismu musel být podle Girarda tak silný, že u vývojových předchůdců člověka vedl k probuzení nového neinstinktivního typu pozornosti, který lze považovat za počátek lidského vědomí. Zástupná obět - ne nějaká konkrétní, ale obět jako univerzální symbol - se tak stala výchozím bodem kolektivního i individuálního vědomí a základním stavebním kamenem sociálního řádu a veškeré kulturní logiky. Obět tak zde představuje prvotní kulturní signifiant či metasignifiant [srv. Krapfl 1999: 26-27; srv. také Mueller 1996].

14 V moderní době nacházíme ozvěny tohoto mechanismu v honech na čarodějnice, různých pogromech, antisemitismu, militantním nacionalismu atp. 
Když Girard dál zkoumá instituci zástupné oběti, řada indicií jej vede k závěru, že postava oběti je v primitivních kulturách vnímána ambivalentně: ztělesňuje jak velmi dobré, tak také velmi zlé síly, je zároveň zhoubná a blahodárná, je zdrojem smrtelného strachu i objektem nábožného uctívání. Kolektivní obět v archaické mysli představuje bytost, která vládne nad společenstvím jakousi tajemnou mocí, jejíž jedna stránka ztělesňuje sociální rozklad a krizi, násilí a smrt a druhá štastné vyústění této krize, (znovu) zrození řádu a život. Girard velmi dobře objasňuje souvislosti, z nichž tato - na první pohled obtížně pochopitelná - ambivalence pramení, v následující pasáži (namísto termínu „zástupná obět“ užívá Girard výrazu „obětní beránek“):

„Obětní beránek tedy sice působí jen na lidské vztahy pokřivené krizí, ale budí dojem, že působí i na její vnější př́ičiny, epidemie, sucho a jiné objektivní pohromy. Za určitým prahem víry působení obětního beránka zcela převrací vztahy mezi pronásledovateli a jejich obětí a z tohoto převrácení pak vzniká posvátno i předkové zakladatelé a božstva. Toto převrácení činí z oběti, ve skutečnosti pasivní, jedinou aktivní a všemocnou prííčinu působící na skupinu, která sama sebe považuje za zcela pasivní. (...)

Vztahy lidí ve skupině se mohou náhle změnit k horšímu nebo k lepšímu. Jestliže tito lidé celý cyklus takovýchto změn připisují kolektivní oběti, která usnadní návrat k normálu, zákonitě z tohoto dvojitého přenosu vyvodí víru v transcendentní mocnost, dvojí a zároveň jedinou, která jim přináší střídavě zmar i spásu, trest i odměnu. Tato mocnost se projevuje prostřednictvím násilností, jichž je obětí a zároveň a především i tajemnou strůjkyní.

Jestliže tato obět může blahodárně působit na ty, kdo ji zabili, navzdory smrti musela obživnout, nebo nebyla doopravdy mrtvá. Kauzalita obětního beránka je tak silná, že ji nemůže zastavit ani smrt. Nehodlá se oběti jakožto přičiny vzdát, a proto ji v případě nutnosti alespoň na čas vzkřísí, učiní nesmrtelnou a vytvoří všechno, co nazýváme transcendentnem a nadpřirozenem [Girard 1997: 54-55].“

Ztotožňuje-li archaická mysl obět jak s násilnou krizí, tak s jejím spásným vyústěním, je pro ni tato obět tajemným vládcem nad životem společenství. Obět', která je „vnímána jako původce násilí a zároveň zachránce před tímtéž násilím, se stává posvátnou: jediný zdroj božské hrůzy i božského požehnání, spojení dvou projevů posvátného skvěle popsaného Rudolfem Ottem [Bottum 1996].“ Je to právě tento tajemný účinek dvojí povahy - primárně vyvolaný násilím, který je podle Girarda nutné hledat jak za posvátností oběti, tak i za veškerým posvátným (primitivní posvátné má stejně ambivalentní povahu, jako posvátná obět') ${ }^{15}$. Girardovou hlavní tezí zde je, že posvátné či snad lépe řečeno, prožitek tohoto posvátného $\mathrm{v}$ mysli archaického člověka, představuje souhrn účinků, které má násilí na archaické vědomí a na vztahy uvnitř společenství. Girard posvátné ukazuje jako dehumanizované a exteriorizované násilí, kterému lidé archaických kultur nejsou schopni rozumět jako svému vlastnímu násilí, ale vnímají je jako tajemnou vnější moc. Lidé v dřívějších dobách totiž vnímali násilí a jeho účinky téměř výhradně

15 Girard ukazuje, že bez pochopení dvojznačnosti násilí, resp. jeho účinků, nemůžeme naplno porozumět dvojaké roli, jakou posvátné sehrává v různých náboženských fenoménech. Girard si zde všímá, že dualitu posvátného lze vystopovat dokonce i na etymologické rovině. Latinské slovo sacer je totiž možné přeložit nejen jako „posvátný“, ale také jako „prokletý“. Až dalším jazykovým vývojem došlo k potlačení negativního významu, což vedlo ke vzniku odvozeniny, která již poukazuje jen na blahodárnou stránku posvátného, totiž výrazu sanctus. Tento sémantický posun Girard připisuje klesajícímu povědomí o přímé souvislosti mezi násilím a posvátným [srv. Girard 1977: 265]. 
V „dehumanizované podobě; to znamená pod klamným pláštíkem posvátného [Girard 1977: 30]“. Jak Girard upozorňuje, ve starších kulturách se na násilí pohlíží jinak, než jak je dnes vnímáme my. Archaickému člověku se jeví jako něco vnějškového, jako síla, které není možné naplno porozumět a ovládat ji. Násilí zde spadá do kategorie přírodních živlů jako jsou lesní požáry, bouře nebo epidemie. Z toho důvodu náboženství

\begin{abstract}
„(...) lidem dává návod, co musí a nesmí dělat, aby zabránili opakování destruktivního násilí. Když zanedbávají rituály a porušují zákazy, přivolávají na sebe nadpřirozené násilí (...). Pouze mechanismus zástupné oběti je může zachránit; všemocné násilí rozhodne, že „provinilci“ již byli dostatečně „potrestáni“, a opět se stahuje do zásvětí a společenství zpovzdálí sleduje; stále je ovšem natolik blízko, že nepřestává vyvolávat bázeň a úctu, která je potřebná pro záchranu člověka.

My (...) považujeme boží hněv za něco iluzorního. Ve skutečnosti ovšem jde o hrozivou skutečnost [tamtéž: 259].“
\end{abstract}

Vrátíme-li se ve světle řečeného k problematice rituálu, vidíme, že primitivní náboženský rituál, jehož je obětní mechanismus základním prvkem, nepředstavuje v rámci Girardova schématu nic jiného než opakování účinků obětního mechanismu [srv. Marr 1998: 594]. Původně spontánní mechanismus se tak postupně stává ritualizovaným základem lidské kultury a předpokladem jejího zachování. Jak vysvětluje girardovský badatel Leo Lefebure, primitivní lidé hledali kvůli obavám z nespoutaného násilí rituální způsoby, jak reprodukovat mimetickou krizi i její obětní vyústění, aby tím

„(...) usměrnili násilí a zabránili jeho dalšímu šíření. 'Př́íznivé násilí’ bylo vyvoláno, aby zahnalo 'zhoubné násilí'. To je také důvod, proč rituály na celém světě žádají lidské a zviŕřecí oběti. Posvátné se podle Girarda zpočátku projevuje jako násilí zaměřené na obětní cíl, obětního beránka. Každá kultura dosahuje rovnováhy na základě toho, že napětí vycházející z mimetické rivality a násilí zaměřuje na obětní beránky. Tento mechanismus usměrňuje a vypuzuje násilí, takže život společenství může pokračovat. Když se mimetické napětí vrací, hrozí nová krize a je opět třeba posvátného násilí [Lefebure 1996: 1227].“

\title{
Druhý pilíř mimetické teorie a problematika mýtu
}

Vedle rituálu představuje nedílnou součást primitivních náboženství a archaických kultur mýtus. Podobně jako rozbor románové struktury dříve přivedl Girarda k odhalení základního (mimetického) vzorce lidských vztahů, rozborem struktury mýtu Girard zase odkrývá schéma skrývající se v základech sociální struktury.

Girardovy rozbory mytologie vycházejí z jednoho ze základních předpokladů jeho myšlení, totiž že „texty jak odhalují, tak i skrývají sociální dynamiku světa, ve kterém jsou vytvářeny [Culbertson 1996]“. Z toho důvodu provádí Girard „strukturální“ zkoumání řady mýtů či jejich antických dramatických zpracování ${ }^{16}$ a zjištuje, že na jednotlivé

16 Girard si všímá, že hlavní rozdíl mezi původními verzemi starých mýtů a jejich antickými dramatickými adaptacemi je v tom, že zatímco mýty skrývají pravou povahu vztahů v rámci určitého konfliktu, nebo jej prezentují ve zkreslené podobě, tragické adaptace se tuto skrytou pravdu snaží odhalovat. Slouží tak vlastně jako nástroj demýtizace, protože autor antického dramatu „obětní krizi znovu přivádí k životu, skládá dohromady rozptýlené kousky dokládající násilnou reciprocitu a vyvažuje jednotlivé prvky, které byly promíchány v procesu 'mytologizace'. (...) Tragédie všechny lidské vztahy vtěluje do jednotné podoby tragického sporu. (...) Tragédie mytologickým námětům navrací prvek násilí [Girard 1977: 64-65].“ 
mýty je nutné pohlížet jako na „retrospektivní ztvárnění obětních krizí, zpětný výklad těchto krizí z hlediska kulturního řádu, který vznikl na jejich základě [Girard 1977: 64]“. Všímá si přitom, že v mýtech nejrůznějších kultur se s železnou pravidelností opakují shodné motivy, přičemž jedním z nejčastějších je téma prvotního chaosu. Ten bývá zpodobován jako stav, kdy mezi nebem a zemí neexistují jasné hranice, bohové se pohybují mezi lidmi, a kdy „bohové, lidé i zvířata nejsou jasně rozlišeni [Girard 1997: 39]“. Jiným tématem odkazujícím k prvotnímu chaosu bývá kosmický konflikt „na počátku věků“, ${ }^{17}$ souboj mýtických postav nebo válka (často se jedná o konflikt mezi dvojčaty nebo sourozenci ${ }^{18}$ ), kdy z těchto střetů povstává svět nebo se rodí daná kultura; jindy se jedná o souboj mýtického hrdiny s nestvůrami atp. Dalším charakteristickým prvkem mýtických př́běhů je podle Girarda zrůdnost mytologických postav. U řady z nich nacházíme nejrůznější tělesné anomálie a deformace, jiné jsou „poskládány“ z nejrůznějších částí živých bytostí. V souvislosti s těmito motivy si Girard klade otázku po jejich společném nevyjádřeném jmenovateli. Právě na jeho základě je podle něj možné určit, o čem mýty ve skutečnosti vyprávějí, jaká je skutečná mýtická struktura. Jeho závěrem zde je, že uvedeným mýtickým motivům jsou společné prvky nerozlišenosti, ztráty rozdílů a krize struktury (jakožto průvodní jevy násilné reciprocity).

Girard tento svůj závěr dále rozvíjí rozborem psychosociálních souvislostí reálných historických perzekucí a perzekuční mentality. Všímá si, že historické perzekuce zpravidla bývají reakcí na nějakou krizovou situaci - at̉ už je to hladomor, epidemie, přírodní katastrofa a podobně - která je zvlášt příznivá pro vznik davu. Právě dav pro Girarda nejlépe reprezentuje společenství zbavené odlišností, jež přirozeně tíhne k pronásledování a hledá, kde by vybilo svou energii, kterou „uvnitř““ vygenerovalo [Canetti 1994: 12-20]. Girard vysvětluje:

„Dav má vždy sklon někoho perzekvovat, nebot ho nezajímají přirozené příčiny toho, co ho znepokojuje a co ho mění v turba. Dav ze své podstaty hodlá jednat, ale přirozené přričiny nedokáže ovlivnit. Hledá tedy nějakou dostupnou př́činu, která by jeho hlad po násilí ukojila. Členové davu jsou vždy potenciální pronásledovatelé, nebơ touží vyčistit společenství od nečistých prvků (...) [Girard 1997: 23].“

Vnitřní dynamika davu je přitom taková, že si své oběti volí podle určitého klíče, který Girard označuje jako perzekučními stereotypy. Oběti davové mentality bývají totiž především obviňovány ze stereotypních zločinů, mezi které patř́ vražda, incest nebo jiné sexuální zločiny, dále travičství, znesvěcování či čarodějnictví. Obět je také zpravidla

17 Pod vlivem badatele Adolpha Jensena se Girard u mýtů zaměřuje právě na problém počátku a ptá se, zda se „něco naprosto zásadního na počátku skutečně nestalo“. Dochází k závěru, že (prvotní) vražda, o které velké množství mýtů vypráví, musela v nějakém ohledu hrát důležitou roli. Girard říká, že neobvyklé „množství vzpomínkových obřadů, které nějak souvisejí se zabíjením, nás vede k domněnce, že onen prvotní akt musel být aktem vraždy. Freud si ve svém Totemu a tabu tuto skutečnost jasně uvědomuje. A pozoruhodná míra shody mezi obětními rituály z různých míst svědčí o tom, že vždy šlo o vraždu stejného charakteru [Girard 1977: 92]“.

18 Girard si v mýtech všímá motivů, které odkazují na násilnou reciprocitu a z ní vzešlou krizi rozlišování. Jedním velmi typickým je podle něj motiv znepřátelených bratrů. Mluví v této souvislosti o tom, že ačkoliv většinou máme „podvědomou tendenci považovat bratrský vztah za láskyplný, mytologické, historické a literární příklady, které si lze vybavit, ovšem říkají něco jiného: Kain a Ábel, Jákob a Ezau, Eteokles a Polyneikes, Romulus a Remus (...). Rozšiřrenost motivu znepřátelených bratrů v řecké mytologii a v dramatických adaptacích mýtů vyjadřuje stále se opakující obětní krizi, jež je opakovaně vyjadřována stejným symbolickým způsobem [Girard 1977: 64]“. 
vybírána z nějaké sociálně okrajové skupiny, např. může jít o cizince, Židy, staré lidi, ženy či jiné osoby, které z nějakého důvodu žijí na okraji společnosti nebo v ní nejsou pevně integrovány. U obětí davových perzekucí také často nacházíme nějakou tělesnou vadu, postižení či jiné znamení, které je viditelně odlišuje od ostatních. Všechny tyto stereotypy přitom spojuje to, že vždy odkazují k odchylkám vůči normě, k podstatným odlišnostem v rámci dané struktury. Jak Girard objasňuje, zvláště viditelné je to u fyzických anomálií.

\begin{abstract}
„Lidské tělo je systém anatomických odlišností. Vada nebo zmrzačení znepokojuje, protože působí jako destabilizující dynamismus. Zdá se, že ohrožuje systém jako takový. Lidé se ji snaží nějak vymezit, ale nemohou; rozrušuje kolem sebe odlišnosti, které se stávají zrůdné, mísí a ruší se navzájem, dokonce je nebezpečí, že zmizí úplně. Odlišnost nepatřící do systému děsí, protože upozorňuje na základní rysy systému - na jeho relativitu, křehkost, smrtelnost [tamtéž: 29].“
\end{abstract}

Přítomnost fyzických anomálií spolu se stereotypními obviněními (zajímavé je, že tato obvinění mají společné to, že domnělé zločiny útočí na základní sociální či náboženské struktury, takže se vlastně jedná o zločiny „nerozlišovatelství“) a faktem sociálního outsiderství (kdy se jedinec stává středem pozornosti opět proto, že se nějak vymyká, že nezapadá do určité struktury) přivádějí Girarda k závěru, že mezi základními perzekučními stereotypy a hlavními mytologickými motivy existuje zřejmá podobnost. Formuluje tezi, že mýty jsou ve skutečnosti prríběhy dávných perzekucí a že jejich původ je třeba hledat „ve skutečném násilí spáchaném na skutečných obětech [tamtéž: 32]“. Mýtus tedy podle něj představuje hrubě zkreslený výklad skutečných perzekučních dějů a představ, který nabývá na síle $\mathrm{v}$ důsledku dlouhodobého působení mechanismu zástupné oběti, takže mýtické př́běhy pak již nelze dešifrovat jako reálné perzekuční události.

K takovému zkreslení (mýtizaci) podle Girarda dochází jednak proto, že dávné oběti jsou sakralizovány (ve formě prvotních božstev, ${ }^{19}$ mýtických hrdinů, uctívaných předků či božských králů) a následně - už jako součást posvátného kultu - začleněny do posvátného kulturního př́iběhu (mýtu). Mytologickému zkreslení napomáhá i skutečnost, že mytologické oběti jsou zpravidla zrůdné, což je důsledek toho, že jsou v nich kombinovány perzekuční stereotypy, které jsou ovšem oděny do posvátného hávu, takže pod maskou božstva či mýtické postavy pak již nejsme schopni zahlédnout tvář skutečné oběti. A to i přesto, že v mýtech nacházíme stereotypní zločiny v těch nejtěžších podobách, včetně vražd, znásilnění, zmrzačení či jiných forem brutálního násilí, jichž je plná např́iklad řecká mytologie. Tyto př́iběhy nás ale nijak nepohoršují z toho důvodu, že jsou sakralizovány, a tedy vyprávěny s mýtickým významovým posunem. Přistupujeme k nim proto jako k samozřejmým výstřelkům božských postav a ani nás nenapadne pravý původ těchto motivů. Girard v této souvislosti upozorňuje, že když se např́klad

„(...) Zeus změní v labut', aby svedl Lédu, vůbec nepomyslíme na zločin obcování se zviŕaty. Když se Pásifaé narodí Mínótaurus, bud’ nás to ani nenapadne, nebo obviníme z nechutnosti spisovatele, který takovou představu navozuje. A přitom se zde nic neliší od (...) hrozné středověké smyšlenky o Židovce z Binzwangenu, která prý porodila selata. Nereagujeme na stejný príběh stejně podle toho, zda v něm

19 Tato primitivní božstva ve skutečnosti zosobňují zvnějšněné masivní lidské násilí, které se zrodilo z mechanismu zástupné oběti. 
tušíme nebo vnímáme nebo naopak nevnímáme perzekuční následky. Estetické a poetické zpracování využívá tisícero způsobů jak perzekuční stereotypy upravit, tedy (...) zakrýt všechno, co by mohlo ukazovat na prvotní mechanismus obětního beránka, který vedl ke vzniku daného textu [tamtéž: 92-93].“

Zatímco podle Girarda uvedené souvislosti většinou unikají při výkladu mýtů, při četbě textů historických perzekucí jsou hned zřejmé. Čteme-li například autentické zápisy z čarodějnických procesů, je - navzdory mnoha motivům shodným s těmi mýtickými - ihned zřejmá absurdní povaha vznesených obvinění. Zpravidla okamžitě rozpoznáme, že nevinné oběti se zde staly obětními beránky svého společenství, at už z jakékoliv příčiny. Mytologie ovšem podobný výklad znesnadňují, protože sakralizace mýtického děje i jeho aktérů od samého počátku podsouvá jeho vnitřní logiku, která skrývá a převrací skutečné vztahy. Také my sami vlastně propadáme moci dávno proběhlé sakralizace. Girard v této souvislosti uvádí př́klad jednoho z nejznámějších mýtů, Oidipova př́běhu, a ukazuje, že Oidipús představuje doslova „sbírku“ perzekučních stereotypů typických pro stereotypní obvinění v čarodějnických procesech. Oidipús je odložené dítě, má tělesnou vadu, je obviněn z vraždy, incestu, morálního a fyzického otrávení společnosti. $V$ jeho př́padě nás ani nenapadne, že by se kdysi nějaký skutečný Oidipús mohl stát obětním beránkem svého společenství, které se ocitlo v krizi, a že by se z něj až následně, v procesu mýtizace, stal bájný královský syn, jemuž „osud určil“ spáchat několik zločinů najednou.

Dalším faktorem, který podle Girarda komplikuje dekódování mýtů jako reálných perzekučních událostí, je to, že v mýtické struktuře postupem času dochází k vývoji, který ještě více maskuje perzekuční původ těchto př́běhů. Jak již víme, posvátné stejně jako posvátná obět má v primitivních společnostech ambivalentní povahu. Girard si ovšem všímá, že s časem dochází k postupnému rozkladu tohoto primitivního posvátného a spolu s ním také k proměně mytologie. Původní dvojznačná božstva se rozdělují na dvě složky, na dobrou a zlou, přičemž původní božstvo či mýtická postava je postupně očištována od všech negativních rysů, až nakonec vznikají dokonalé bytosti chránící společenství. Druhá, ničivá a zhoubná složka, která původně byla součástí téže posvátné postavy, nemizí, ale přesouvá se na mýtickou obludu či netvora, ztělesnění čistého zla, jenž se pak stává protivníkem dobrého božstva. Dva původně sjednocené prvky se tak oddělují a dávají vzniknout dvěma protikladným bytostem a dvěma protikladným světům.

Girard je přesvědčen, že musíme mít na paměti právě tento mechanismus, uvažujeme-li o původu vývojově mladších mytologických motivů, jako je např́klad střet dobrého božstva či bájného hrdiny s obludou, která ohrožuje společenství. Původní motiv prvotního násilí nebo smrti prvotní oběti, z níž v procesu mýtizace vzniklo prvotní božstvo či mýtický zakladatel světa, se neztrácí, ale v posvátném př́iběhu dochází $\mathrm{k}$ přeskupení vztahů. Nyní už pro společenství nebo kulturu není záchranou nebo předpokladem jejího vzniku mrtvý bůh či mýtický předek, ale naopak mrtvý netvor, jehož zabíjí či vyhání dobrá božská postava. Ovšem ani tato fáze ještě nepředstavuje poslední vývojové stádium mytologie. Proměna mýtických obsahů postupuje dál, až se nakonec zcela vymaňuje z posvátného rámce náboženského systému a bere na sebe podobu bájí, hrdinských legend nebo pohádek.

Posledním momentem, který podle Girarda znesnadňuje dekódování mýtických obsahů, je proces tzv. estetizace božstev, jenž lze nalézt už u antických filozofů a dramatiků. 
Girard tvrdí, že tito autoři usilovali o „reformaci“ božstev a mýtů, protože tradované mytologické zločiny a násilnosti nebyly slučitelné s jejich ideálem božstev, které by lidé měli uctívat. Girard si myslí, že hlavním důvodem tohoto estetizačního trendu zkrátka bylo, že antičtí autoři intuitivně cítili, „že by jejich bohové mohli v jádru být jen všemi opovrhovanými a pošlapávanými obětmi“. Podle něj se zde jedná o proces, který zpětně „osvětluje vývoj každé vyvíjející se mytologie [tamtéž: 90]“, kdy dochází k postupnému „očištování“ primitivních božstev a mytologií od původních motivů. Protože si lidé stále více „přejí bohy, jež by nebyli ani zločinci, ani oběti“, postupně

\begin{abstract}
„(...) stírají násilí a zločiny (...), jejich znaky obětí i samotnou krizi. Někdy význam krize převracejí a nerozlišenosti bohů a lidí se pak přikládá utopický smysl.

Čím víc se nějaké společenství vzdaluje od násilnických počátků svého kultu, tím více slábne smysl rituálu a posiluje se morální dualismus. Bohové a všechny jejich činy, včetně těch nejohavnějších, byli nejprve vzorem v rituálech. (...) Přichází však okamžik, kdy lidé už hledají jen vzory morálnosti a požadují bohy zproštěné veškerých chyb. Nářky takového Platóna nebo Eurípida, který také chtěl bohy reformovat, nesmíme brát na lehkou váhu. Odráží se v nich rozpad prvotního posvátna a dualistická tendence, která chce bohům zachovat jen ty př́iznivé stránky; rozvíjí se úplná ideologie, spočívající v tom, že se bud’ posvátno promítá na démony a démoni se stále více odlišují od bohů, jako je tomu v bráhmanismu, nebo že se to škodlivé považuje za neplatné, za něco přidaného k původněǰšímu náboženství, které jako jediné odpovídá reformátorovu ideálu. Posunutím tohoto ideálu do smyšlené minulosti si však ve skutečnosti reformátor počátek vymýšlí podle svého. Ostatně právě tento posun mění původní krizi v idylu a utopii [tamtéž: 91].“
\end{abstract}

\title{
Druhý pilíř mimetické teorie a problematika posvátné oběti a posvátného krále
}

Zastavme se nyní u významu a sociální funkce posvátné oběti, která představuje další důležitý prvek Girardova teoretického schématu. Již byla řeč o tom, že hlavní úlohou obětního rituálu je napodobení mechanismu zástupné oběti, a tím „udržení násilí vně společenství [tamtéž: 91]. “ A odkazují-li mýty k počátku, pak podle Girarda vždy odkazují k „zákládajícímu“ násilí, k obětní krizi, která právě skrze mechanismus zástupné oběti dává vzniknout novému řádu. Jsou-li tedy mytologie př́iběhem o násilných počátcích řádu, pak obětní rituál představuje mechanismus, jímž společenství preventivně opakuje blahodárné působení prvotního násilí. Jedná se zde o rituální, „ř́izenou“ re-inscenaci hlavních fází sociální krize za podmínek, které nejen umožňují udržet násilí pod kontrolou, ale aktivně využít jeho blahodárných účinků na sociální strukturu. ${ }^{20}$

V tomto rituálním mechanismu, ze kterého povstává prvotní sociální řád a jenž je základním kamenem veškeré kulturní logiky, přitom sehrává ústřední roli postava posvátné oběti, jejíž charakter je - jak už víme - dvojí. Je zároveň zlá i dobrá, čistá i nečistá, zhoubná i blahodárná, obávaná i uctívaná, prokletá i požehnaná. Tento dualismus posvátné oběti reflektuje dvojakost primitivního posvátného, které je odrazem dvojakého vnímání dehumanizovaného a zvnějšněného násilí (tj. jak jeho sociálně rozkladného, tak také sociálně jednotícího účinku). Právě tady leží klíč k hlubšímu porozumění

20 Girard k tomu říká, že vždy „když je obětní akt doprovázen požadovaným účinkem a škodlivé násilí je přeměněno v blahodárnou sociální stabilitu, je to vnímáno tak, že bůh násilnou obět přijal a pozřel jí. Nemělo by nás proto překvapovat, že všechny teologické systémy podřizují obětní úkony pravomoci božstva. Úspěšná obět brání násilí v tom, aby se vrátilo do stavu imanence a reciprocity; to znamená, že dále posiluje roli násilí jako vnějšího, transcendentního a blahodárného vlivu [Girard 1977: 266]“. 
posvátnosti rituálních obětí v archaických kulturách, kdy je jim připisována odpovědnost za původní chaos (tj. oběł jako zhoubný škůdce), ale také za nastalý ráa a mír (tj. obět jako blahodárný zachránce a spasitel). ${ }^{21}$ Obětní beránek se tak „stává božstvem v archaickém slova smyslu, tedy nabývá všemohoucnosti zároveň pro dobro i pro zlo [Girard 2008: 60]“. Obětní mechanismus zde tak rovněž lze chápat jako jakýsi stroj na výrobu božstev, kdy obět je nejprve démonizována, aby následně byla divinizována.

Girard v této souvislosti také nabízí nové vysvětlení vývoje společenské struktury, evoluce sociálních institucí a politické moci jako takové. Zásadně se přitom odchyluje od všech tradičních teorií. Jak již víme, prvotním obětem je v důsledku pozitivního účinku jejich smrti na společenský řád připisována nadlidská moc a jsou nábožně uctívány, tzn. dojde k jejich sakralizaci. Obětní rituál pak jen institucionalizuje onen prvotní spontánní mechanismus, jehož hlavní funkce spočívá v pravidelném „očištování“ společenství od vnitřního násilí, čímž se obnovuje a posiluje sociální struktura a soudržnost skupiny. Z hlediska dějin lidských společností je podle Girarda klíčovou institucí posvátná monarchie (a postava posvátného krále). Ta ovšem podle něj není ničím jiným než př́mým evolučním výtvorem obětního mechanismu. ${ }^{22}$ Girard vymezuje vztah mezi institucí posvátné monarchie a institucí posvátné oběti následovně: královskou moc a prestiž chápe jako pozdější vývojové stádium posvátnosti, kterou disponuje prvotní obět. Ta je totiž „nadána nadlidskou, děsivou mocí proto, že je vnímána jako zdroj chaosu i řádu“, a část posvátné úcty, kterou prvotní obět vyvolala, přechází také na všechny pozdější rituální oběti, takže je nutné se soustředit právě „na tuto autoritu, abychom objevili zdroj veškeré politické a náboženské moci [Girard 1987: 52-53]“. Tento vývoj si můžeme představit tak, že posvátná královská moc a autorita postupně vyrostla z bázně a úcty společenství vůči posvátné oběti, kdy došlo k tomu, že období uctívání budoucí rituální oběti se postupně prodloužilo natolik a nabylo takové intenzity, že už nebylo myslitelné ji obětovat. Posvátná úcta a bázeň se tak proměnila v reálnou (posvátnou) moc. Stále ale přitom jde o stejný mechanismus, rozdíl je jen v tom, jak je daným společenstvím interpretován. Girard osvětluje vztah mezi posvátnou obětí, božstvem a posvátným králem v následující pasáži:

„Monarchie zdůrazňuje interval mezi výběrem oběti a jejím usmrcením; jedná se zde o obět, která je stále naživu, která ještě nebyla obětována. $V$ príípadě božstva je naopak zdůrazněna situace, kdy je obět již usmrcena a posvátno tím bylo vypuzeno ze společenství. $V$ prvním případě je moc posvátného přítomna, je živá a činná v postavě krále; ve druhém př́padě je naopak nepřítomná v „postavě“ božstva.

21 Girard zde vysvětluje, že jakmile „pochopíme roli, jakou hraje generativní násilí, začne být jasné, jak může posvátno v sobě zahrnovat tolik různých protipólů. Někdy kolem sebe sjednotí celou komunitu, aby společnost ochránilo a obnovilo kulturní řád, jindy se zase zdá, že na tento řád působí rozkladně. (...) Násilí je (...) uctíváno do té míry, do jaké poskytuje lidem život v řádu a míru. Nenásilí se zde jeví jako svévolný dar, který člověku poskytuje násilí (...) [Girard 1977: 258-259].“

22 Ačkoliv ji Girard považuje za nejdůležitější, instituce posvátné monarchie podle něj není jedinou kulturní institucí, která se vyvinula z obětního mechanismu. Girard je přesvědčen, že v obětním mechanismu je třeba hledat i kořeny domestikace zvířat (tradiční výklad, motivovaný hospodářskou výhodností, je podle něj chybný). Podobně i mechanismus směny mezi skupinami jako prazáklad obchodu má podle Girarda rituálně-náboženské základy, at už se jedná o „výměnu“ násilí formou války, která v archaických společnostech slouží i jako zdroj rituálních obětí, výměnu žen nebo zboží. Podobně ani obřady související s uctíváním mrtvých, které bývají označovány za prvotní znak každé kultury, nelze podle Girarda uvažovat odděleně od obětního mechanismu [bliže viz Girard 1987]. 
(...) Protože se božstvo nachází vně, (...) obětování zde nemůže být přesným napodobením počátku. Protože ale obětování přesto zůstává ekvivalentem prvotní události, obvykle se nakonec vyvine do nějaké oslabené formy. Stále se ale bude mít za to, že dává vzniknout posvátnému - v menším množství -, které bude ze společenství vypuzováno, a tak bude posilovat a živit božstvo. Zde bude původ myšlenky významu obětního mechanismu jako obětování posvátným silám.

(...) V monarchii je dominantním prvkem to, co prèdchází obětování; u božstva je jím naopak to, co obětování následuje. (...)

Všichni opakují, že král je „živým bohem“, nikdo už ale neříká, že božstvo je mrtvým králem nebo „nepřítomným“ králem, což vlastně znamená totéž [tamtéž: 55-57].“

Girard své vysvětlení vztahu instituce posvátné oběti a posvátného krále rozvádí a objasňuje na dalších př́íkladech. Všímá si například, že jeden severoafrický kmen od svého krále v období korunovace nebo při jiných slavnostních př́ležitostech očekává incestní či násilné chování, at už skutečné nebo jen symbolické, popř́padě konzumaci zakázaných pokrmů. Tomuto jevu lze podle Girarda porozumět pouze v kontextu rituálních provinění, jichž se král svým jednáním dopouští:

„Od krále je občas žádáno, aby se dopustil všech zakázaných skutků, které jsou myslitelné. Obsáhlost provinění (...) prozrazuje, koho má vlastně král zosobňovat: vzor provinilce, člověka, kterému není nic svaté a který se bez obav dopouští všech možných prohřeškủ [tamtéž: 105].“

Královský incest má $\mathrm{v}$ daném rituálním rámci směřovat $\mathrm{k}$ tomu, aby postava krále ztělesňovala nejvyšší možnou míry nečistoty a poskvrnění. Král zde tak vlastně symbolizuje prvotní obět, je to „nový Oidipús“. Podle Girarda, aby král mohl v rámci rituálního schématu „dostát“ vzneseným obviněním, je „nucen dělat to, z čeho byl pưvodně obviněn [tamtéž: 106] “. Nikoliv sám za sebe jako za konkrétního jedince, ale jako symbolická postava ztělesňující instituci rituální oběti. Girard tuto posloupnost dobře ilustruje na př́kladu mýtu jiného afrického kmene:

„Incest [v rámci tohoto mýtu] vede ke vzniku společnosti; je zdrojem míru a hojnosti mezi lidmi. (...) A i když se zpočátku může zdát, že incest ospravedlňuje akt oběti, ve skutečnosti je to tak, že akt oběti legitimizuje incest. Král vládne na základě toho, že má být usmrcen; není ničím jiným než obětí, která čeká na to, aby byla obětována, člověkem který má být popraven. Obětní rituál nepředstavuje první, ale ritualizovanou formu pưvodního výbuchu kolektivního násilí [tamtéž: 107].“

U jiného kmene královský rituál probíhá tak, že se král odebere na uzavřený pozemek, kde popíjí zakázané nápoje a spáchá incest. Během této fáze rituálu příslušníci kmene zpívají píseň, jíž vyjadřují svou nenávist ke králi a touhu se jej zbavit. V dalším fázi dochází k symbolické popravě krále. Král, jako ztělesnění nečistoty, dotykem své ruky přenáší veškeré své poskvrnění na krávu, která je následně obětována. Král, původně v roli oběti, z ceremonie vychází jako absolutní vládce:

„Ačkoliv byl král zpočátku téměř sám obětován, později řídí rituály, ze kterých vychází jako obětník par excellence. Na této dualitě není nic překvapivého; pouze potvrzuje roli, kterou jsme připsali zástupné oběti, tedy schopnost ovládnout veškeré násilí [tamtéž: 111].“ 
V této souvislosti je také důležité Girardovo vysvětlení společenského postavení krále, které vychází z účinků mechanismu zástupné oběti. Girard zde královskou moc chápe jako vývojový „produkt“ posvátnosti rituální oběti:

\begin{abstract}
„Rozhodující zde je připsání autority (...) osobě, která je vybrána za budoucí obět a která zpětně čerpá svou moc a prestiž z usmiřujícího účinku prvotní oběti. S časem se stává vliv zástupné oběti stálejším a trvalejším, prvky, které jsou s tímto vývojem v rozporu postupně mizí, a postavu krále nahrazuje jiná obět', bud’ lidská nebo zvířecí. Vše, co má co do činění s protikladnou stránkou nejvyšší autority - provinění a ponížení, zhoubné násilí a obětní trest -, zůstává na čistě „symbolické“ rovině a brzy se zcela ztrácí z dohledu. (...) Posvátná královská moc se proměňuje v čistou královskou moc, v moc politickou [tamtéž: 304].“
\end{abstract}

Povšimněme si také, jak se v postavě posvátného krále odráží dualita násilí i princip nerozlišování evokující prvotní mimetickou krizi. Jak bylo řečeno, v osobě krále mizí jasné hranice mezi kategoriemi, protože je „zároveň bůh, člověk a divoké zviŕe [tamtéž: 252]“. Posvátný král v sobě sdružuje vlastnosti, které nacházíme u mýtických a božských postav; je nebezpečný a zároveň blahodárný, je zločincem a zároveň zachráncem vzbuzujícím posvátnou úctu, je to - řečeno s Girardem - „posvátná zrůda“. Jak Girard také ukazuje, právě kvưli této dualitě a $\mathrm{z}$ ní plynoucího zvláštního, nejednoznačného postavení krále se na něj v některých afrických monarchiích vztahují zvláštní pravidla, jejichž hlavním cílem je ochránit společenství před možnými ničivými účinky posvátného, které král zosobňuje:

\begin{abstract}
„Př́́tomnost postavy, která je silně prostoupena posvátným, v centru společenství představuje mimořádný problém. $\mathrm{V}$ některých př́padech má král zakázáno dotýkat se země, protože panuje obava, že by ji mohl kontaminovat a způsobit tak smrt svých poddaných. Někdy má král také zakázáno se sám nakrmit; to, že by se dotkl jídla, by mělo za následek, že by již nebylo vhodné pro obyčejné smrtelníky. A existují kultury, kde je tato posvátná zrůda pečlivě ukryta před zraky ostatních - ne kvůli své vlastní ochraně, ale kvůli ochraně svých poddaných, kteří by padli mrtvi, pokud by na nich ulpěla pohledem [tamtéż: 268].“
\end{abstract}

Velká míra shody mezi postavou posvátné oběti a posvátného krále vede Girarda k závěru, že posvátný král čerpá svou posvátnou zrůdnost právě ze zrůdnosti prvotní oběti. Lze tak říci, že v rámci dané sociální struktury představuje posvátný král jakousi fixovanou kolektivní pamět posvátné monstrozity prvotní oběti a přejímá ústřední roli, kterou tato obět hrála při zrodu sociálního a kulturního řádu. To také umožňuje lépe porozumět, proč právě postava posvátného krále stojí v samém středu sociální struktury a kulturního řádu. Král je tímto řádem, je středem, ve kterém je sociální struktura ukotvena. ${ }^{23}$ Jedinečnou pozici posvátného krále (v různých kulturách po celé dějiny) je třeba chápat na základě toho, že král stojí nad pravidly, nad kulturním řádem, protože tato pravidla a tento řád vyrůstají z něj; právě on je určuje a udržuje v chodu. Král je posvátný proto, že představuje posvátnou „osu“ společenství; z pohledu dané komunity z něj

23 Božský král zde představuje jakýsi posvátný „svorník“, je ručitelem dobrého chodu vesmíru, garantem pokračování života a příznivého fungování společnosti. Jakmile si uvědomíme, že za archaickým pojetím královské moci je nutné hledat pradávné rituální schéma, pak také lépe porozumíme tomu, jak se rituální mechanismus - s králem jako ústřední postavou - postupně vyvíjí až ve stabilní instituci; a že např́́klad město či městský stát jako důležité fáze ve vývoji civilizace původně vznikají jako královské sídlo, jako místo pozemského pobytu živého božstva [Jacques Le Goff 2004: 512-513]. 
vše vychází a v něm se vše sbíhá. Právě zde je proto třeba hledat prazáklady sociálního a kulturního řádu a veškeré politické moci. ${ }^{24}$

\section{Závěr}

Představuje-li problém sociální ontologie, tedy otázka vzniku a udržení sociálního řádu [Barša 2001: 9-10], jedno z nejdůležitějších témat sociologie a sociálního myšlení, a můžeme-li otázku, jak je sociální ráa vůbec možný, považovat za základní otázku sociologie vůbec [Keller 2006: 99], pak lze Girardovo dílo považovat za významný příspěvek k soudobému sociálnímu myšlení. Je tomu tak proto, že se v mnohém vymyká tradičnímu uvažování o původu a zdrojích sociálního a politického řádu, které vychází z dominantní racionalisticko-osvícenské tradice. ${ }^{25}$

Mimo oblast sociální ontologie může být Girardovo myšlení pro sociology a sociální teoretiky podnětné všude tam, kde se zabývají problematikou náboženství, souvislostmi mezi společností a náboženstvím či politikou a náboženstvím, otázkou posvátného či moci, ${ }^{26}$ popřípadě rolí těchto fenoménů při fungování sociální struktury a sociálních či politických institucí. Tady všude může být Girardovo myšlení inspirativní pro nové pohledy a nové promýšlení starých otázek.

Neméně zajímavé by bylo prozkoumat Girardovo dílo v širším rámci sociologického myšlení s důrazem na ty autory a teorie, kde důležitou roli hrají fenomény násilí, posvátného nebo moci. ${ }^{27}$ Stálo by například za zvážení číst vybraná díla sociologických klasiků girardovskou optikou a prozkoumat, zda takový postup může v nějakém směru přinést nové porozumění starým myšlenkám a tématům. Tento úkol by byl o to zajímavější, že u mnoha z těchto klasiků nacházíme řadu motivů, které tvoří jádro Girardovy teorie. $^{28}$

24 Girardova teorie otevírá velké téma vztahu mezi posvátným a mocí a otázku, jak tyto dva fenomény souvisejí se vznikem a udržením sociální struktury. Vynikající studie, která pracuje s motivy posvátného a moci v girardovském duchu (byṫ bez konceptu psychologické mimesis jako základního východiska), je práce historika Marca Blocha Králové divotvưrci. Autor zde především ukazuje, že o královské moci nelze uvažovat odděleně od fenoménu posvátného a že dějiny moci jsou až jakousi „horní vrstvou“ dějin posvátného a jeho proměn. Bloch ve své práci přesvědčivě dokumentuje, že ačkoliv král v historii plnil ve vztahu ke společnosti celou řadu funkcí (role hlavy státu, soudce, vojevůdce), v očích svých poddaných byl něčím mnohem víc, králové byli totiž především považováni za posvátné osoby. Pravým zdrojem královské moci tak byla víra v zázračné schopnosti a nadpririrozený původ králů (od toho se také odvijí doktrína posvátné královské krve a „urozenosti“; zde je třeba hledat počátek moci královských rodủ a dynastií). Po většinu dějin vládlo přesvědčení, že božští králové disponují nadpřirozenou mocí, která ovlivňuje nejen řád a strukturu dané společnosti, ale také prrírodu a př́rodní jevy - tedy řád jako takový. Vědomí těchto souvislostí je velmi důležité i pro soudobé zkoumání moderních společností a moderních států, protože dějiny Evropy jsou až do pokročilého novověku především dějinami královské moci. Je to právě královská moc, která dominuje vývoji evropských institucí, a ostatně i dnes na dějiny tohoto období pohlížíme především jako na dějiny královských dynastií [srv. Bloch 2004: 26-28, 61-63, 73].

25 Máme na mysli především myšlenkovou tradici počínající sociálními teoretiky „společenské smlouvy“, jako jsou Thomas Hobbes, John Locke či Jean-Jacques Rousseau, jejichž vliv na sociální a politickou teorii je dodnes velmi silný.

26 Fenomén moci nás zde zajímá především v sociálně-teoretickém či antropologickém smyslu, tedy především jako síla, která společnost integruje a udržuje ji v chodu [srv. Halík 2004: 23-24].

27 Problematika politické moci a jejích proměn představuje jedno z velkých témat historické sociologie. Všude tam, kde se sociologie zabývá vztahem moci, násilí a vznikem a udržením sociálního řádu, může být Girardovo hledisko velmi užitečné a inspirativní [srv. např. Kilias 2009].

28 Např́klad už Auguste Comte se zaměřuje na problematiku sociálního řádu např. ve svém důrazu na „sociální statiku“"). Ústřední roli v jeho myšlení sehrává náboženství, nebot právě to je tím, co společ- 
Dalším úkolem, který by stál za úvahu, by bylo zformulovat Girardem inspirovanou autonomní teorii společnosti ${ }^{29}$ vycházející ze zákonitostí psychologické mimesis, která by zde po Girardově vzoru byla považována za základní antropologickou konstantu, za univerzálně působící psychosociální sílu. Význam takového úkolu by spočíval v tom, že by tady makro-sociologická teorie byla kombinována s psychosociální teoriî pracující s „mikroúrovní“ sociální reality, tj. s mechanismy psychologické mimesis, což se bezprostředně dotýká jednoho z velkých témat sociologie - vztahu jednotlivců a subjektivity na straně jedné a objektivní, „vnější“ sociální struktury na straně druhé. ${ }^{30}$

Je zřejmé, že by zde šlo o náročný a ambiciózní úkol, jenž by si žádal několik přípravných kroků, včetně kritického přezkoumání Girardova teoretického systému a jeho zasazení do širšího sociologického diskurzu. V této souvislosti lze za dva hlavní „přípravné“ úkoly považovat tyto. Za prvé, kritické prozkoumání Girardova myšlenkového systému; za druhé, v rámci přípravy pro fundovanou debatu v rámci sociologického diskurzu, načrtnutí základních obrysů girardovské teorie společnosti. V takové situaci nelze než začít „u kořenů“ a především provést srovnání Girardových myšlenek s Durkheimovou teorií společnosti a s jeho výkladem vzniku a udržení sociálního řádu. Také se s Girardovou pomocí pokusit nově podívat na dávný teoretický střet mezi Durkheimem a Tardem [srv. Keller 2007: 176-179, 198, 203] a hledat odpověd na otázku, zda ten spor má stále opodstatnění (a pokud ano, tak jaké); a nebo zda je s pomocí Girardovy mimetické teorie možné vytvořit mezi Durkheimem a Tardem nový myšlenkový most. ${ }^{31}$ Jde o úkol nadmíru zajímavý také z toho důvodu, že Girard je sice ukotven v „durkheimovské“ tradici francouzského sociálního myšlení, ${ }^{32}$ ale vůdčím

nosti integruje. Rovněž pro Émila Durkheima představuje problematika náboženství jedno z hlavních témat jeho sociologie. Ve svém díle předkládá komplexní teorii náboženství, kde se mj. zabývá vztahem mezi posvátným a profánním, zkoumá význam rituálu, který upravuje vztah mezi posvátnou a profánní rovinou skutečnosti, zamýšlí se nad vztahem náboženství a společnosti, tematizuje otázku kolektivního vědomí a jako samostatným problémem se například zabývá otázkou - mimochodem velmi „girardovskou“ - neomezené lidské touhy a jejími „anomickými“ důsledky. Podobné průniky lze nalézt i u Maxe Webera týkající se vztahu náboženství a racionalizace, postupné „odkouzlování světa“ nebo u Georga Simmela s jeho motivy reciprocity lidských vztahů, rivality a konfliktu nebo vztahu mezi touhou a penězi jako médiem umožňujícím společné vědomí a sociální integraci. Lze nalézt řadu dalších příkladů, kdy mezi klasiky sociologie a Girardem existuje mnoho styčných ploch.

29 Taková teorie by mohla posloužit nejen jako teorie sociálního řádu, ale nabídla by i nový rámec pro porozumění vztahu mezi touhou, rivalitou, posvátným a mocí a rolí, jakou tyto fenomény sehrávají v životě soudobé konzumní společnosti.

30 Zkoumání tohoto problému by získalo nový rámec v tom, že je nyní možné se jím zabývat v situaci, kdy mimetické „mikromechanismy“ začínají dostávat solidní empiricky podložené základy, konkrétně v oblasti neurověd a vývojové psychologie. Pro více informací k empirickým zjištěním podporujícím základní východiska Girardovy teorie studie Scotta Garrelse [Garrels 2006]. Pro více informací k psychosociálním souvislostem a novým empirickým zjištěním souvisejícím s Girardovou mimetickou teorií viz internetové stránky Imitation, Mimetic Theory, and Religious \& Cultural Evolution: A Templeton Advanced Research Program, < www.mimetictheory.org >

31 Dotýkáme se zde jednoho z velkých témat sociologie, tj. vztahu sociální „mikro-reality“ a sociální „makro-reality“, a tedy vlastně dvou proti sobě stojících sociologií. Tento teoretický spor nejlépe symbolizuje právě střet mezi Durkheimovým sociologickým funkcionalismem s jeho důrazem na prvotnost makrostruktur a Tardovou mikrosociologií zdůrazňující prvotnost interakcí na sociální „mikro-úrovni“, které až sekundárně konstruují sociální „makro-struktury“.

32 Girard sám mluví o tom, že v roce 1978 vyšel v reakci na jeho knihu Násilí a posvátné v časopise Diacritics text anglického etnologa Victora Turnera, který si, jak Girard říká, „první všiml mého ‘durkheimovství’, které sám odmítal, ale v mé knize viděl nejpřesvědčivější způsob, jak Durkheima překonat, a přitom mu zůstat věrný [Girard 2008: 34]“. 
motivem jeho teorie je zároveň fenomén mimesis, tedy imitace, která zase tvoří klíčový prvek tardovské sociologie.

Z uvedených důvodů bych se rád dál věnoval zkoumání a rozvíjení Girardových myšlenek právě naznačeným směrem. Již jen letmý pohled nám dostatečně ukazuje, že jde o cestu, kterou stojí za to podrobněji prozkoumat přinejmenším z hlediska sociologické teorie. To vše představuje témata pro další studie. 


\section{Literatura}

Barša, Pavel. [2001]. Imanence a sociální pouto. Brno: CDK.

Bloch, Marc. [2004]. Králové divotvůrci. Studie o nadpřirozenosti přisuzované královské moci, zejména ve Francii a Anglii. Praha: Argo.

Boorstin, Daniel J. [1996]. Člověk tvůrce. Historie lidské imaginace. Praha: Prostor.

Bottum, J. [1996]. Girard Among the Girardians. First Things 61 (March 1996) [online]. dostupné na First Things.com., < http://www.firstthings.com/article/2009/01/005-girard-among-thegirardians-34 > [12. 10. 2009]

Canetti, Elias. [1994]. Masa a moc. Praha: Arcadia.

Culbertson, Diana. [1996]. Anthropology, Theology, and René Girard. First Things, No. 65 (August/ September 1996), [online]. dostupné na First Things.com., < http://www.firstthings.com/ article/2007/10/augustseptember-letters-36 > [10. 10. 2009]

Garrels, Scott R. [2006]. Imitation, Mirror Neurons, and Mimetic Desire: Convergence Between the Mimetic Theory of René Girard and Empirical Research on Imitation. Contagion: Journal of Violence, Mimesis, and Culture, Vol. 12-13 (2006), No. 12, s. 47-86.

Girard, René. [1977]. Violence and the Sacred. Baltimore: The Johns Hopkins University Press.

Girard, René. [1987]. Things Hidden Since the Foundation of the World. Stanford: Stanford University Press.

Girard, René. [1997]. Obětní beránek. Praha: Nakladatelství Lidové noviny.

Girard, René. [1998a]. Lež romantismu a pravda románu. Praha: Dauphin.

Girard, René. [1998b]. Victims, Violence and Christianity. The Month. London Review of Christian Thought 31 (April 1998), No. 4, s. 129-135.

Girard, René. [2002]. Dostoevsky’s Demons. Joseph Frank Finishes his Biographical Masterpiece. Review of Joseph Frank, The Mantle of Prophet, 1871-1881. (2002). The Weekly Standard 7 (May 20, 2002), No. 35, dostupné na The Weekly Standard.com., http://www.weeklystandard.com/Content/Protected/Articles/000/000/001/228ijiyn.asp [10. 7. 2010]

Girard, René. [2008]. O původu kultury. (Hovory s Pierpaolem Antonellem a Joãem Cezarem de Castro Rocha). Brno: CDK.

Halík, Tomáš. [2004]. Vzýván i nevzýván. Evropské přednášky k filozofii a sociologii dějin křestanství. Praha: Lidové noviny.

Keller, Jan. [2006]. Úvod do sociologie. Praha: Sociologické nakladatelství.

Keller, Jan. [2007]. Dějiny klasické sociologie. Praha: Sociologické nakladatelství.

Kiłias, Jaroslaw. [2009]. Válka, armáda, stát a národ: byrokracie, disciplína a nacionalismus. Historická sociologie 1 (2009) No. 1, s. 45-64.

Kirwan, Michael. [2008]. René Girard: Uvedení do díla. Brno: CDK.

Krapfl, James. [1999]. Reflections on the Revolution in Czechoslovakia. M. A. Thesis from Central European University in Budapest.

Lefebure, Leo D. [1996]. Victims, Violence and the Sacred: The Thought of René Girard. The Christian Century 113 (December 1996), No. 4, s. 1226-1229.

Le Goff, Jacques: Doslov. In. Bloch, Marc. [2004]. Králové divotvưrci. Studie o nadprirrozenosti přisuzované královské moci, zejména ve Francii a Anglii. Praha: Argo, s. 485-519.

Marr, Andrew. [1998]. Violence and the Kingdom of God: Introducing the Anthropology of René Girard. Anglican Theological Review 80 (Fall 1998), No. 4, s. 590-603.

Mueller, Markus. [1996]. Interview with René Girard. [online]. Anthropoetics 2 (June 1996), No. 1. dostupné na Anthropoetics.ucla.edu., < www.anthropoetics.ucla.edu/archive/anth0201. pdf > [10. 7. 2010]

Taylor, Simon J. [1998]. Cruciform Anthropology: an Introduction to the Thought of René Girard. The Month. London Review of Christian Thought 31 (April 1998), No. 4, s. 136nn.

Veblen, Thorstein. [1999]. Teorie záhalčivé tř́dy. Praha: SLON.

Williams, John (ed.). [1996]. The Girard Reader. New York: The Crossroad Publishing Company. 
Marián Kišš (1976) vystudoval na Katedře politologie a evropských studii Univerzity Palackého v Olomouci a na Katedře politických věd Central European University v Budapešti. V letech 2000-2006 pracoval jako asistent senátora Josefa Jařaba. V roce 2007 působil téměr půl roku jako stážista v Evropské komisi v Bruselu, v kabinetu José Barrosa. Od konce roku 2008 pracuje na Ministerstvu zahraničních věcí ČR. Od podzimu 2009 je doktorandem na katedře sociologie Filozofické fakulty University Karlovy v Praze. Dlouhodobě se zajímá o politickou filozofii a sociální teorii, zejména pak o problematiku moci. $V$ rámci svého doktorského studia se zabývá myšlením francouzského sociálního a kulturního teoretika René Girarda. 